報文 $\mathrm{CA} S$ シ ス テ ム の 特 性*

\begin{tabular}{|c|c|c|c|c|c|}
\hline （昭和36年11月 4 日受理） & 会 & 員 & 青 & 野 & 英 \\
\hline & & & 村 & 上 & 文 \\
\hline & & & 新 & 井 & 克 \\
\hline
\end{tabular}

目的

CAS システムの構成概要を説明するとともに, その基礎的な特性を明らかにする.

成 $\quad$ 果

カード給綿法としてのリザーブ ボックス給綿は，ラップを成形することなくカードに供給する方法であるが， その方法ではピア，モーションを除いても，充分均斉なカード スライバが得られる.

ユニットホッパ, ブランチ コンベヤによる各カードへの給綿の分配は, ニニットホッパの給綿量が，不感帯. 幅に対して充分であれば，二位置制御によって円滑に行なわれる.

自動仕上練条機（S A D）のスライバむら制御方式は，開ループ修正方式であるが，その設定は，制御系の総合 ゲイン定数 $K_{f}$ を $\quad K_{f}=1$

$$
\gamma=\frac{\text { (記憶時間 })-(\text { 実在位相進み時間 })}{(\text { 集中時定数 })}
$$

として $\gamma=-0.6$ の值に調整する.

工程結合方式を新しい段階に導いた自動第一練条機（SRD）では，再重合されたスライバのつぎ目は，追いつ ぎの形となり，SADでの記憶時間の適正な設定が，必須の条件となる。

ドラフト倍率 360 倍の超ハイ ドラフト精紡機は，紡出条件を適正にすれば成功である.

\section{CAS システムの流れ}

この紡績方法は混打綿工程，梳綿工程打よび練条 $(2$ 工程）を結合して構成した $\mathrm{BCD}$ ユニットとオートド ッファ（TAD）を配したUHD精紡工程の 2 つの工程 から成り立っている：第 1 図とその構成概要を゙示す。
原綿は混綿, 開綿, 除じんされた後, ラップを゙成形す ることなく，コンデンサホッパ(2) に送られる.コンデ ンサホッパをへた綿は, カード一列の供給をうけもつ ユニットホッパ(3)そそれぞれ均等に配分して供給さ れる。

ユニットホッパをへた綿は, ブランチ コンベヤ(4)上

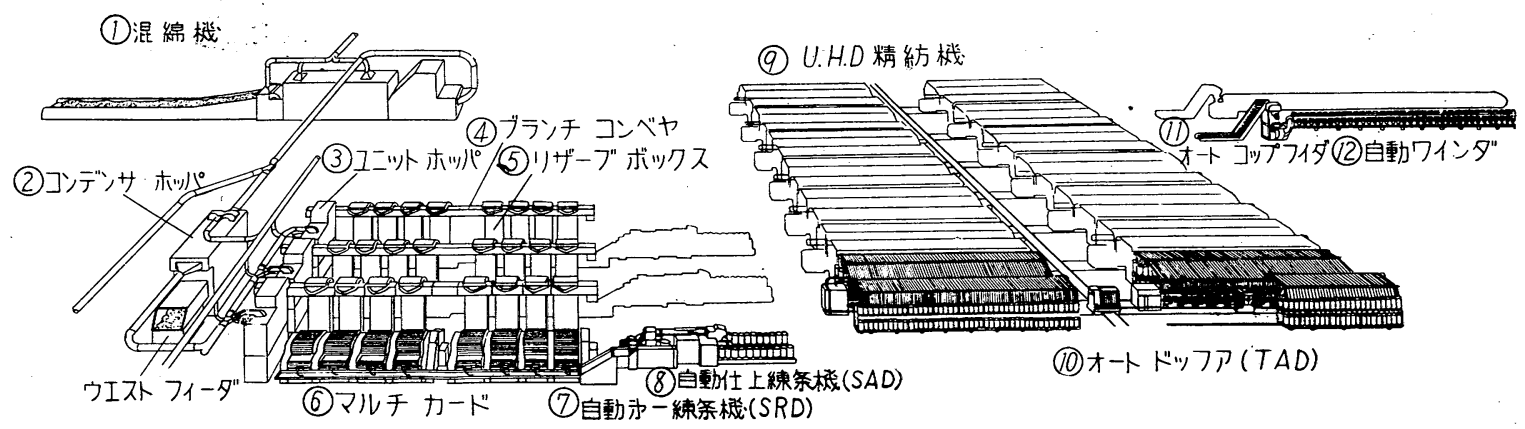

（第 1 図）東洋結連続自動紡䥊装置（CAS システム）

* Process Dynamics of Toyobo Continuous Automated Spinning System.

** H. Aono, F. Murakami, K. Arai, Member. 東洋紡績株式会社 
に、ほば定量供給の形で供給され

る.ブランチ コンベヤ上の綿は, 各カードに装置されたリザーブ ボックス (5)に均等に配分される。

リザーブ ボックス下端からく い出される綿層は, フリース状て 彷って，これが各カードのフィー ドローラに供給される。

混綿 1 七只トの生産能力は, 約 $200 \sim 300 \mathrm{~kg} / \mathrm{hr}$ であって,これは

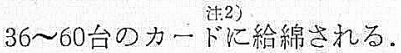

カードの一列は 6 10台の集団 になっており，原料和よび番手に よって台数がきるる。

カードから紡出されたスライバ は，各列ごとにスライバコンベ ヤ上で重合され，各列ごとに1台 の自動第 1 練条機 (SR R ) (7) 沈 供給される. 自動第 1 福条機はカ ードスライバを゙重合してドラフ トしこれるそれぞれホールケ ンスに收め，スライバの方を反 転して, 再び9〜11 本の重合を行 なら役目をするが，全自動のプロ グラムで運転されている.

自動第一綀条機の絬出スライバ ば，9 11 本が重合されて自動仕 上練条機 (SAD) (8) K供給され る. ここでの紡出スライバは, 直 接精紡にかかるので，完全に管理 状態になければならない，そのた めに量目の自動調整装置を有して いる. ケンス交換の自動化はるら ろ九であるが，空ケンスの送入， 满ケンスの搬出るまた自動化され，連続運転がでさるよ うになっている。紡速は自動第一練条，仕上練条ともに $120 \mathrm{~m} / \mathrm{min}$ である.

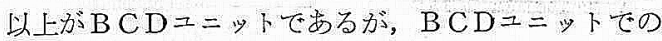
作業員活，操業西で従来工程の $20 \%$ にすぎないので,

※ 東洋紡式重続自動紛績装置 (Toyobo Continuous Automated Spinning System)

※ SRD は Sliver Reversing Drawer の略称 でスライバ自動収容供給装置をるよばれる

※\% SAD 将 Super Auto-Drawer の略称

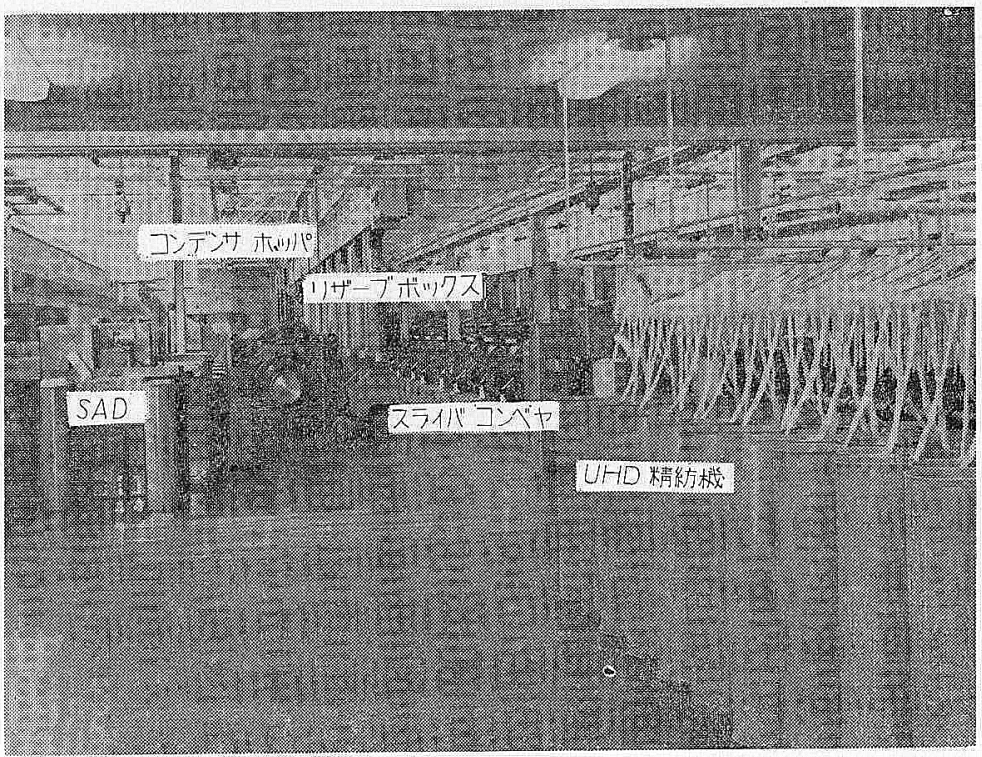

(写真 1 a) C A S I 場 $の$ 全 景

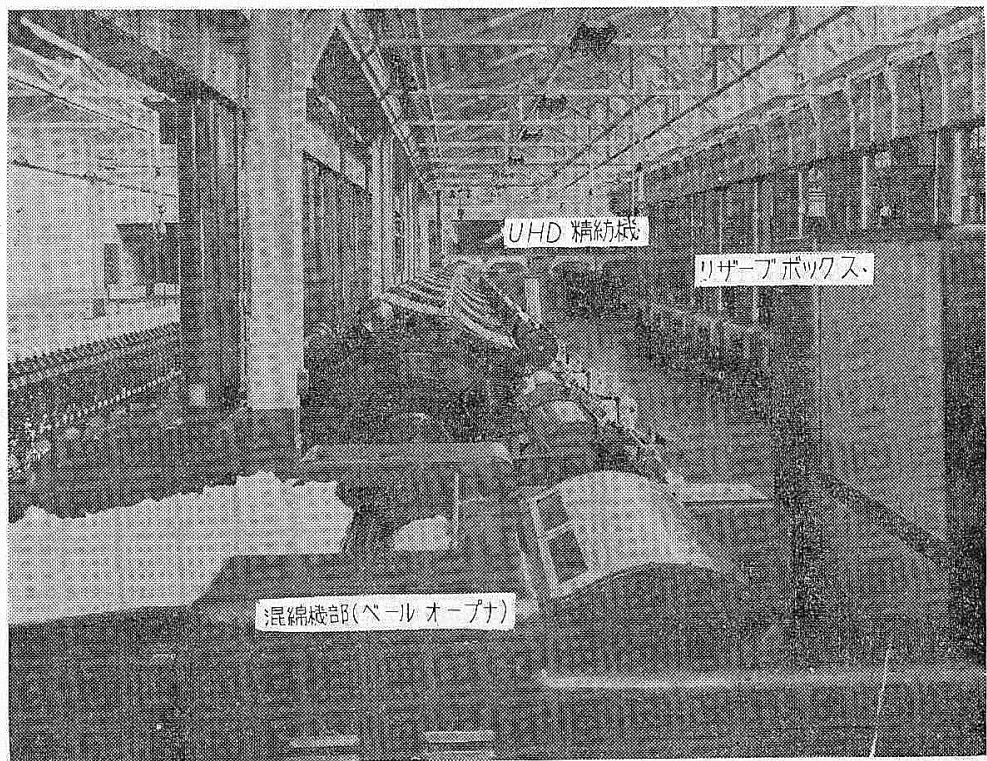

（写嘪 1 b ） C A S I 場 の 全 景

万一の故障に祭しての処置を考えて，早期発見のため集 中表示盤方式そ採用し，全ュニットの状態柱管理下に招 かれている. 作前員への指令は無線電話で与えられる。

カード，スライバコンベヤ，自動第一練条機打よび 自動仕上練条譏の一連の機械隹，起動，演止の過渡状態 Кおいても，定常運転中に拈いてる，1\%以上の速度差 があっては，スライバを損賃させ，スライバぎれまねは スライバたるみとなって運転に支障を来たしたり，テン ションドラフトとなってスライバの品質を損じたりす 


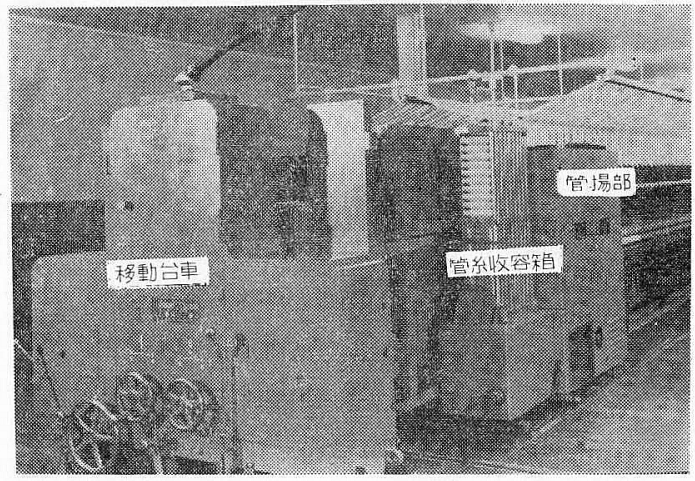

$$
\text { (写 真 2) }
$$

UHD精絞機とオートドッファ（TAD）

る、そこで完全な同調運転が必要である、 $\mathrm{BCD}=ニ ッ$ トでは装置の設備費を低廉にするために，巻線形誘導電 動機を用い，簡易セルンンの方法によって同調運転させ ている.

こうして生産されたBCDユニ机のスライバは，定 目を管理さ机, 䋴維平行度, 量目変動率, ウース夕值と もに，在来工程の仕上枯条スライバ以上の品質を有して いる，そこで精紡までに不用意な工程をはさむことは好
名て $40 \mathrm{~s}$ 紡出ならば 70〜80台（約 30000 錻）の精綡 機の管揚作業を受け持つことができる。

以上でCASシステムの流机を゙説明したが，こうして みると機械的特性の検討を要する個所は，カードスラ イバの品質を左右するリザーブ ボックスの效果，自動 第一練条機汇拾外る重合效果，自動仕上練条機の量目管 理効果抢よび同調運転法, それにUHD精紌機の泩能な どである. 以下にそれらの各論について述べてみよう。

\section{2.リザーブ ボックスの性質}

ブランチコンベヤからの綿はリザーブ ボックスに投 入されるが，リザーブ ボックス内の綿は自重によって 下方に特しだされる。䄱しだされた綿は，コレクチング ローラを通った後は,フリース状となってカード供給に 都合がよい，第 3 図にその原理図を示す。

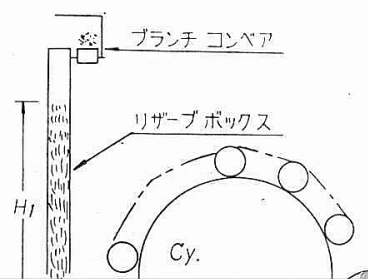




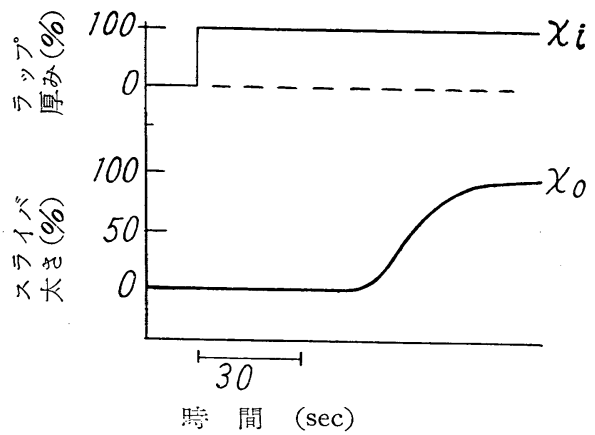

（第4㮀） フラットカードの過渡応答

の紡出量目变動 $x_{0}$ は, 第 4 図火示寸上万な時間的変化 をする。そのときの現象を（1）式であらわせば

$$
X_{0}(s) / X_{i}(s)=G_{p}(s)
$$

であるから

$$
X_{0}(s)=\frac{K_{p} e^{-L_{p}(s)}}{1+T_{p}(s)} X_{i}(s)
$$

であって $X_{i}(s)=1 / s$ としたときの応答を示すもので, 時間関数になおぜば時間を $t$ とし

$$
x_{0}=K_{p}\left(1-e^{-\left(t-L_{p}\right) / T} p\right)
$$

$$
\text { ただし }\left(t-L_{p}\right)<0 \text { のときは0とする. }
$$

第 4 図を゙トレースして $(2)$ 式の定数をきめれば $L_{p}$ $=50(\mathrm{sec}), T_{p}=17(\mathrm{sec})$ の值をうる。

こんどはりザーブ ボックスをつけた第 3 図のような 場合に，このような $L_{p}, T_{p}$ の值をきめてみよう。し かしこのときは，まえと同じょうな試験が，簡単にはで きないので，遟った方法を用いる。

リザーブボックスを完全に満たして和き，給綿を停 止して紡出をつづける．紡出するにしたがって，綿層の 高さの変動 $x_{i}$ は減少するが，その減少状態は近似的に 直線である．それを利用して綿層の高さに速度入力の変 動 $x_{i}$ を与えたものとして取り扱うことができる。こう してえた結果をプロットしたものが第 5 図である.

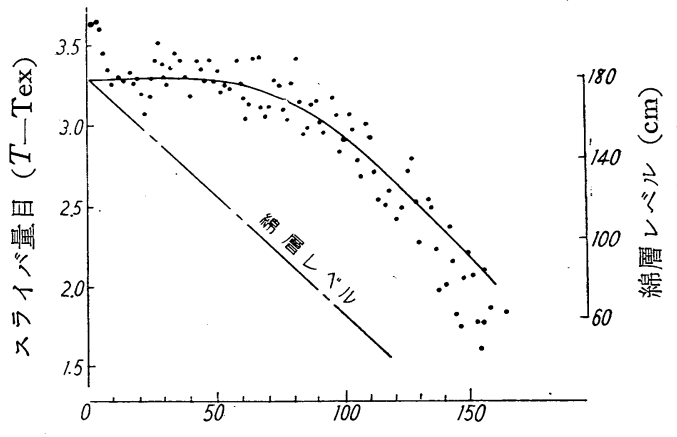

時 閒 $(\mathrm{sec})$

（第 5 図） 綿層レベルと紡出量目の動特性
このときは $(1)^{\prime}$ 式に物いて $X_{i}(s)=-1 / s^{2}$ とした ときの応答であるから式は

$$
x_{0}=T_{p} K_{p}\left(-e^{-\left(t-L_{p}\right) / T_{p}}-\frac{t-L_{p}}{T_{p}}+1\right)
$$

の形となる、第 5 図をトレースして抢なじように值をき めると， $L_{p}=270(\mathrm{sec}), T_{p}=294(\mathrm{sec})$ を得る。 この ときの計算値を実線で示したが，綿層レベルの変化があ まり大きくない範囲では，比較的よく一致していること がわかる.すなわら一般のカードと同じ形の伝達関数で 表現できるわ好でるが，むだ時間も時定数もリザーブ ボックスをつけることによって問題なしに大きくなる.

しかしここで制御の難易を表わす係数 $L / T$ の值をとっ てみると，一般カードでは 50/17=3 であるのに対して リザーブ ボックスつきでは $270 / 294=0.92$ となって, 後者の方が $1 / 3$ ぐらいに小さくなり，制御は前者よりる ずっとやりやすいことを示す．制御をしやすいというこ とは，供給量が少しぐらい変化しても，紡出量目には影 響が少ないということである．したがってピアノモー ションによる厚み修正を取り除いても, 綿層レベルの变 動をある程度制御すれば，充分むらの少ない紡出スライ バが得られる。

以上のようにカード スライバの紡出量目は, リザー ブ ボックスの綿層レベルの関数であるが，制御効果を わかりやすくはあくするために，その静的な特性を実験 的にきめると，第 6 図のようになる。すなわち綿層高さ

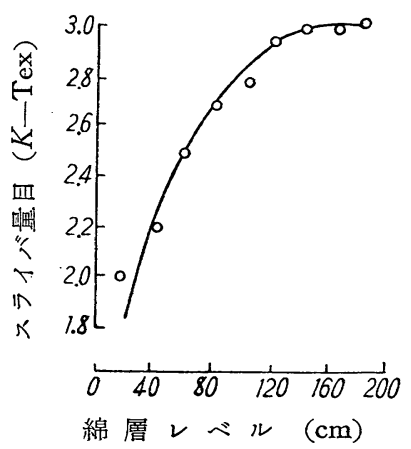

（第6眓）綿層レベルと紡出量目の静特性

が比較的低い間は，その高さに応じて紡出量目は增減す るが，ある程度の高さ以上になると，紡出量目には影響 が少ないようになる. その高さは $160 \mathrm{~cm}$ 以上にあるよ らである。

このような特性であると，たとえば $180 \mathrm{~cm}$ を標準高 さとし, $180 \mathrm{~cm}$ でリザーブ ボックスへの供給をオフと し，160 cm でそれをオンとする二位置制御によって綿 層高さをコントロールすれば，紡出量目には変動が少な 


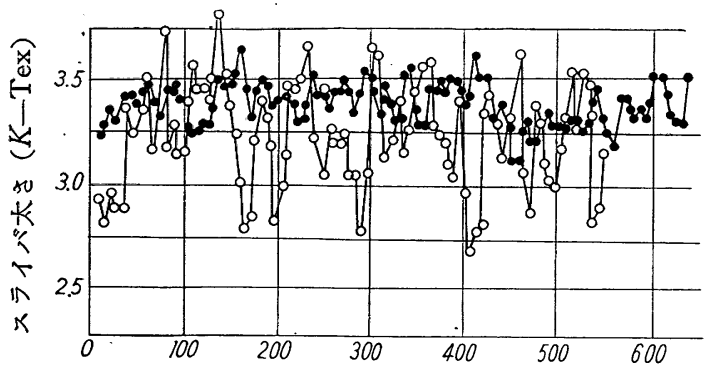

測 定 位 圆 (m)

・・・ザーブ ボックス供給 $\overline{\boldsymbol{x}}=2.89$ grain ○一○ ラップ給綿 $C V=3.32 \%$ $\bar{x}=280$ grain $C V=7.32 \%$

（第 7 図）・カード紡出量目変動

いものになる。

さらにこのような二位置制御によって紡出されたスラ イバ量目（grain/6yd）を，スライバを連続に $6 \mathrm{yd}$ ず つサンプリングして秤量した数列で図示してみると，第 7 図に持いて・印で示したようになる。これを一般のラ ップ供給台と比較してみると，○印のようであって，ラ ップ供給台では量目変動率 $C V=7.3 \%$ であるのに対し て,リザーブ ボックス供給台では, $C V=3.3 \%$ であっ て、リザーブ ボックス供給のほうが変動が少ないこと を゙示している.

このようにリザーブ ボックス中の綿層高さの変動が カードの紡出量目の変動に影響を与えることがわかっ た. ところがブランチ コンベヤに対して, 数台のリザ ーブボックスが連絡していて, 各ボックスに対して, 給綿がそれぞれオン一オフで供給一停止を゙行ならのであ るからここの間の挙動を検討して就く必要がある。

ブランチ コンベヤに対して, 直列にリザーブボック スが数個連結している場合を考兵る. 第 8 図 (a) に示

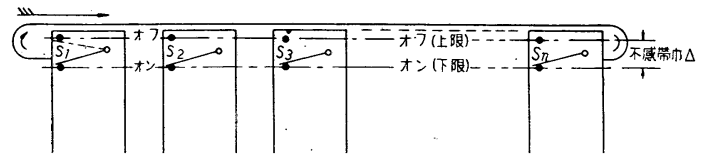

わちスイッチ $S_{n}$ 认よって発せられる．ただしこの第 $n$ 番目のボックスへの給綿機構は $S_{n}$ の信号にかかわらず つね杖はって和り，綿がオーバフロウすること をさけているが，そのためのボックスの綿層レベルの偏 差は非常に小さい.

このような構成になっているとき，ブランチ コンぺ ヤがオンとなって給綿をはじめると，まず供給側に近い リザーブボックスから供給がなされ，順次遠い側に移 ってゆく，近い側の供給がオンになっでれば，遠い側 が同時にオンになっても，そちらには綿ははこばれず， 給綿は全部近い側に扣ちることになる。したがってもし ブランチ コンベャの 給綿量が少ないと，1列のリザー ブ ボックスへの給綿が完了しないまえに，再び供給側 に近いリザーブ ボックスがオンとなり；供給側から遠 いボックスには給綿が円骬行なわれない状態を来す。 そこで二位置の不感帯に対して，充分な給綿能力をるつ ことが必要である.

以上のような条件で綿層レベルの挙動をしらべるわけ であるが，リザーブ ボックス個々の綿層レベルを問題 にすると，式は複雑になってかえって挙動をつかみにく くなり，実用的ではないので，1列のリザーブ ボック スの綿層レベルの平均值的なもの,すなわち 1 列の綿層 レベルの降下の合計値という形で，その挙動を取り扱っ てみよう、符号をつぎのようにきめる。

$Q_{i}:$ ブランチ コンベヤがオンになっているときの 単位時間当り給綿量 $(\mathrm{g} / \mathrm{sec})$

$q_{0}$ : カード 1 台の単位時間当り紡出量 $(\mathrm{g} / \mathrm{sec})$

$h_{i}$ : 給綿量 $Q_{i}$ に対する綿層堆積速度 $(\mathrm{cm} / \mathrm{sec})$ $\left(h_{i} \propto Q_{i}\right) * * * \%$

$h_{0}$ ：綿層降下速度 $(\mathrm{cm} / \mathrm{sec}) \quad\left(h_{0} \infty q_{0}\right)$ ※※※ $\%$

$n:$ リ゙ーブ ボックスの数

$\Delta:$ オ一オフ, スイッチの不感帯幅 $(\mathrm{cm})$

$H: n$ 個のリザーブ ボックスの綿層レベルの降下 合計値 $(\mathrm{cm})$

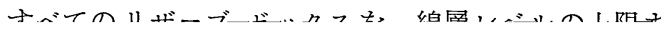


ここに $p=h_{i} / h_{0}$ である. 綿層 レベルのブランチ ンベヤがオンからオフにかわる瞬間の降下合計值 $H_{21}$ は 近似的飞

$$
\begin{aligned}
H_{21} & =h_{0}(n-1) T_{21} \\
& =\frac{n \Delta(n-1)}{p-1}
\end{aligned}
$$

またつぎの回にコンベヤがオフからオンにかわる瞬間 の降下合計値 $H_{12}$ は

$$
H_{12}=H_{21}+\tau h_{0} n=\frac{n \Delta(n-1)}{p-1}+n \Delta
$$

第 2 回目でコンベヤがオフになっている時間 $T_{12}$ は

$$
T_{12}=\tau
$$

この回にコンベヤがオンになっている時間 $T_{22}$ は

$$
\begin{aligned}
& T_{22}=\frac{\tau n h_{0}+H_{21}}{h_{i}-h_{0}}=\frac{n \tau}{p-1}\left(1+\frac{n-1}{p-1}\right) \\
& H_{22}=h_{0}(n-1) T_{22}=\frac{n \Delta}{p-1}\left(1+\frac{n-1}{p-1}\right)(n-1)
\end{aligned}
$$

第 $K$ 番目では

$$
\left.\begin{array}{rl}
T_{1 K}=\tau & \\
T_{2 K}= & \frac{n \tau}{p-1}\left\{1+\frac{n-1}{p-1}+\left(\frac{n-1}{p-1}\right)^{2}\right. \\
& \left.\quad+\cdots \cdots \cdots+\left(\frac{n-1}{p-1}\right)^{K-1}\right\} \\
H_{2 K} & =\frac{n \Delta}{p-1}\left\{1+\frac{n-1}{p-1}+\left(\frac{n-1}{p-1}\right)^{2}\right. \\
& \left.+\cdots \cdots \cdots+\left(\frac{n-1}{p-1}\right)^{K-1}\right\}(n-1)
\end{array}\right\}
$$

定常状態では

$$
\left.\begin{array}{l}
T_{1 \infty}=\tau, \quad T_{2 \infty}=\frac{n \tau}{p-n} \\
H_{2 K}=n \Delta \frac{n-1}{p-n} \quad H_{1 K}=n \Delta \frac{p-1}{p-n}
\end{array}\right\}
$$

すなわち周期 $T_{\infty}$ は

$$
T_{\infty}=\tau\left(1+\frac{n}{p-n}\right)=\frac{p \tau}{p-n}
$$

で, 振幅 $\Delta n$ の振動をし, レベルの上限は $n \Delta(n-1) i$ $(p-n)$, 下限は $n \Delta(p-1) /(p-n)$ のところにおちつく.

給綿量が紡出量の合計の 2 倍であるときの綿層レベル の変化を図示したものが第 8 図（b）である。このとき

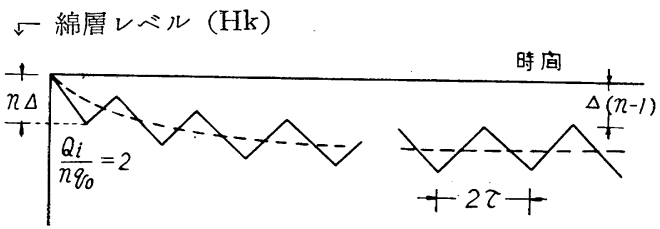

（第 8 図b）綿層レベルの過渡応答
は $Q_{i} /\left(n q_{0}\right)=2$ であって, $p=2 n$ であることを意味す る。（5）式が收束であることが，この系の安定する条 件であって，そ㧈は

$$
\begin{aligned}
\frac{n-1}{p-1} & <1 \\
\text { すなわち } & p>n \\
& Q_{i}>n q_{0}
\end{aligned}
$$

がこの系の安定な条件である，ただし綿層レベルの上下 限を考える必要があり，あまり $Q_{i}$ が小さいことは望ま しくない。

理想的にはレベルの上限が $\frac{1}{2} n \Delta$ となればよいから その条件では

$$
p=3 n-2
$$

である．この条件での綿層レベルの応答を第 8 図 $(\mathrm{c})$ に示す。

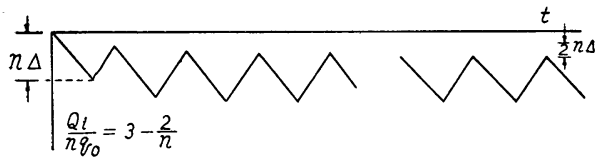

(第 8 図 $\mathrm{c}$ )

\section{3. 自動仕上練条機とスライバ量目の制御}

自動仕上練条機の紡出スライバ番手は厳重に管理する 必要がある。この工程から後の工程では, 紡出量目はま すます細くなり，デリベリ数は增し，1錘当りの生産性 は低くなって，もはや1.本ずつのむらの制御を自動的に 行なうことはできなくなる，この工程が自動管理の最後 の機会である、ことにUHD精紡機を゙用いる場合には, 直接精系となるわけであるから，その意味はずっと重大 である。

むらの制御を開ループ修正方式で行ならか, 閉ループ 制御方式で行ならかは問題であるが, 自動仕上練条機で は開ループ修正方式を採用している. 第 9 図には両方式 による制御効果をむら残留率 $A(u)$ の形で比較した計算

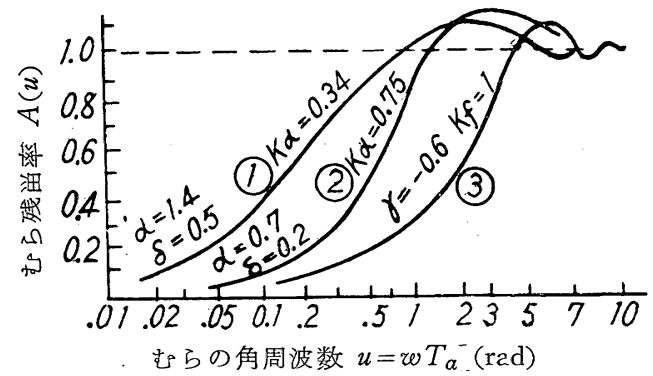

（第 9 図）制御方式とその効果 
結果を示した。このような曲線で制御効果を比較する場 合には，むらの周波数ができるだけ高いところまでむ ら残留率が小さい汪らが効果がよいわけである。

第 9 図で曲線(1)，(2はむだ時間がある場合に，閉ルー プ制御方式を用い（比例ナ積分）の制御を行なった場合 のむら残留率曲線を示す。曲線に注記した $\alpha, \delta$ の值は 制御系の集中時定数 $T_{a}$ を規準として積分時間 $T_{i}$ ，む だ時間 $L_{d}$ を無次元化した值で

$$
\alpha=T_{i} / T_{a}, \delta=L_{a} / T_{a}
$$

であり， $K_{d}$ はゲイン定数である。

曲線(3は開ループ修正方式を採用した場合で， $K_{f}$ は ゲイン定数， $\gamma$ は検出部からドラフトゾーンまでスラ イバが移動するに要する時間 $L_{\boldsymbol{⿰}}$ とその補償のための記 憶装置の記憶時間 $L^{\prime}$ 、との差を無次元化して

$$
\dot{\gamma}=\left(L^{\prime}-L_{f}\right) / T_{a}
$$

である。

また横軸は同じくむらの角周波数 $\omega$ を無次元化して

$$
u=\omega T_{a}
$$

としてとってある.

記憶装置つきの開ループ修正方式を採用したときの曲 線(3は，他に比して制御効果がむらの高い周波数まで拉 よんでいる。一般にむだ時間を伴うのでループ制御方式 では，せいぜい曲線(2)の効果しか期待できない。

このような理由で自動仕上練条機では開ループ修正方 式をとっいるが，紡出スライバの番手がはたして目標通 りになっているかどらかは，やりっぱなしになってしま らのでっそれれをエックする方法を講じている.

自動仕上練条機のサーボ機構を第 10 四に示す．検出 部は機械式であって,メジャリング ローラ $M R$ の変位 としてスライバ太さを検出する。この変位はロッドシ リソダ $R C$ によって機械的に記憶される。ロッドシリ ンダが $1 / 4$ 回転すると, この変位はレバーによって取り 出され, 変位変換器 L I C によって, 比例空気圧信号

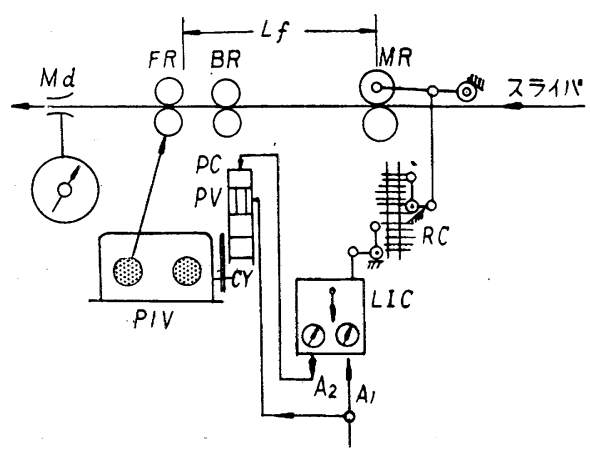

（第10図）S ADサーボ機構の編成
にかえられる。図では $A_{1}$ は一次空気， $A_{2}$ は二次空気 圧の配管を示す，信号空気压は空気圧サーボ モータに 送られる，空気圧サーボ モータはパイロット シリンダ $P C$, パイロット バルプ $P V$, パワーシリンダ $C Y$ お よびその変位に直結するフィード バック レバーからな っている．このパワーシリンダ変位が変速機 PIV の八 ンドルを作動して，フロント ローラ $F R$ の回転数をか 光ドラフトを調整する， $B R$ はバック ローラでこの 回転数は不変である。また PIV ハンドルは標準ドラフ トの設定用にも使用されていて，操作ドラフトは $20 \%$ であるが，その中心值は $1: 4$ の変速比の範囲で自由に 設定することができ，仕掛変更に際しても，ドラフト チ エンジホィールをいれかえるなどの操作は不要である。

ここでこの自動仕上練条機を制御系として，むらの制 御状態を検討して和く必要がある。まずブロック線図を 作る必要があるが，計算を簡単にするために，線形化の ための仮定をいれ，その範囲で検討を進める.

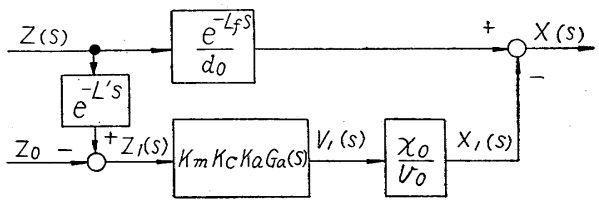

（第11図） S A D制御系プロック線図

ドラフト操作を単にドラフト倍率の逆数を掛算する操 作とみなせば，この制御系のブロック線図は，第11 図 のように与えることができる。ここにスライバの入力太 さを $z(t)$, 出力太さを $x(t)$, ドラフトを $d(t)$, フロ ントローラ速度を $v(t)$ とし，添字 0 は標準值，1は 変動值として示す。 $K_{m}, K_{\boldsymbol{c}}$ はそれぞれ検出部, 制御装 置による比例定数である。また $L_{f}, L^{\prime}$ は前述の（9） 式に説明したと抢りである。

操作部の伝達関数を $K_{a} G_{a}(s)$ とすれば，近似的に

$$
K_{a} G_{a}(s)=\frac{K_{a}}{1+T_{a} s}
$$

ただし $T_{a}$ は集中時定数， $K_{a}$ はゲイン定数である. 第 11 図から制御状態を示す式は

$$
\begin{aligned}
& \frac{X_{1}(s)}{x_{0}}=\left[1-\frac{z_{0}}{v_{0}} K_{m} K_{c} K_{a} G_{a}(s) e^{-\left(L^{\prime}-L_{f}\right) s}\right] \\
& e^{-L_{f} s} \cdot \frac{Z_{1}(s)}{z_{0}} \\
& K_{m} K_{c} K_{a} \frac{x_{0}}{v_{0}}=K_{f} \text { とおいて } \\
& \left(\frac{X_{1}(s)}{x_{0}} / \frac{Z_{1}(s)}{z_{0}}\right)=\left[1-K_{f} \frac{e^{-\left(L^{\prime}-L_{f}\right) s}}{1+T_{a} s}\right] e^{-L_{f} s}
\end{aligned}
$$




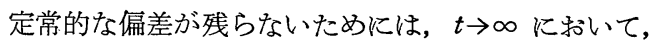

（13）式の右辺が0でなければならない，そのためには $s \rightarrow 0$ であるから

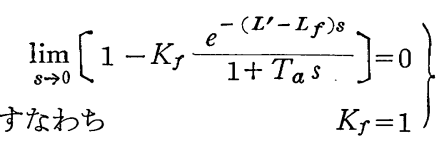

（14）式がこの自動仕上練条機の制御系のゲイン設定 の条件で,この設定は日常つねに守らなければならない。 むら残留率 $A(u)$ はつぎのように定義されている.

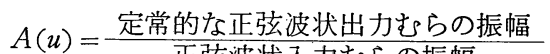

$$
=\left|\frac{X_{1}(j \omega)}{x_{0}}\right| \frac{Z_{1}(j \omega)}{Z_{0}} \mid
$$

ただしいは（10）式で説明したと括りである。そこで 無次元化した形でむら残留率を計算すると（13）式から

$$
A(u)=\left|\frac{X_{1}(j u)}{x_{0}} / \frac{Z_{1}(j u)}{z_{0}}\right|=\left|1-\frac{K_{f} e^{-j \gamma u}}{1+j u}\right|
$$

（16）式について, 設定の条件 $K_{f}=1$ として $\gamma=0.2$ 〜ー1 の範囲でむら残留率を計算したものが, 第 12 図 である.この図からたと究ば $\gamma=-0.6$ の曲線が, 比較

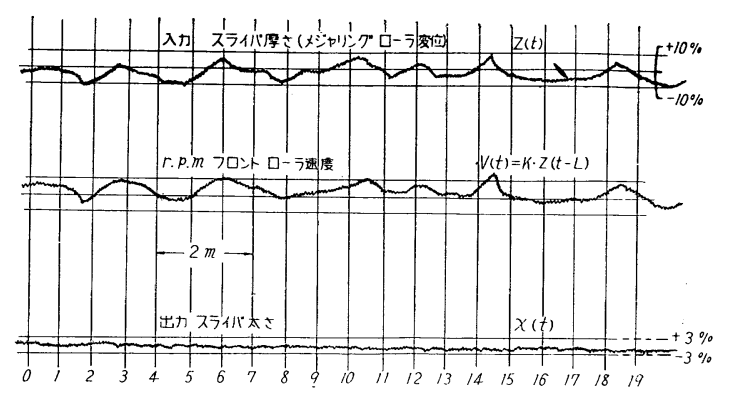

（第13 図） SAD制御装置の働き

が適時に与えられ，紡出スライバの量目が，一定值に管 理されていることがわかる.

参考のためにむらが理論的に消去できる波長を計算し て拉く.む护の角周波数 $\omega$ と波長 $\lambda$ との関係は

$$
\lambda=\frac{2 \pi v}{\omega}=\frac{2 \pi v T_{a}}{u}
$$

である.この制御系の集中時定数は実測の結果は $T_{a} \leftrightharpoons$ $0.2(\mathrm{sec})$ である. $\gamma=-0.6$ に設定して，むらが $1 / 2$ ま で消去できる周波数は第 12 図から注㴒 $u=2$ である. 紡速を $100 \mathrm{~m} / \mathrm{min}$ にとったとすれば，それらの数值を （17）式にいれて

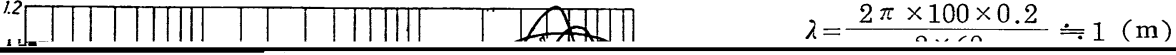


重合で，ドラフト $N$ 倍の操作を $x$ 回行ならとして，それ をそのまま直列結合で連続化しょうとすれば，最終紡速 $V_{x x}$ は，カード紡速 $V_{0}$ に対して

$$
V_{x x}=N^{x} \cdot V_{0} \cdots
$$

となる，ところがそれに並列結合を $y$ 回混用すれば，最 終紡速 $V_{x y}$ は

$$
V_{x y}=N x-y V_{0}
$$

ここで並列結合とするためには，スライバ力向を反転 することを意味し，方向反転操作が最終紡速を制約内に いれる役目をすることを示している．反転操作を具体的 に自動化したのが，この自動第一練条機（SR Dの名む その機能に由来している) である。

たとえばここでの重合はほぼ 8 重合 2 回に相当する. 直列結合をそのます行なったとすれば，最終紡速は $V_{x x}$ $=\delta^{2} V_{0}=64 V_{0}$ であって, カード紡速を $16 \mathrm{~m} / \mathrm{min}$ と しても， $V_{x x}=1024 \mathrm{~m} / \mathrm{min}$ となり，これは結合不可能 な速度である。ところがそのとき 1 回のスライバ方向反 転操作をいれる。尗わち並列結合を 1 回いれると, 最 終紡速 $V_{x y}=8^{2-1} V_{0}=8 V_{0}$ となって, $V_{x y}=128 \mathrm{~m} / \mathrm{min}$ となる。この速度怡結合可能な速度である。

具体的な装置の構造については，ここで割愛せさるを 得ない事情にあるので，㐨許しを願いたい。

自動第一練条機で再重合されたスライバは, そのつぎ 目は追いつぎの形になる。すすおわわずかの時間で10本 のスライバ中，1本がオンーオフの状態になる：その平 均的な時間の経過を図示すれば，第14図のよ5になる。

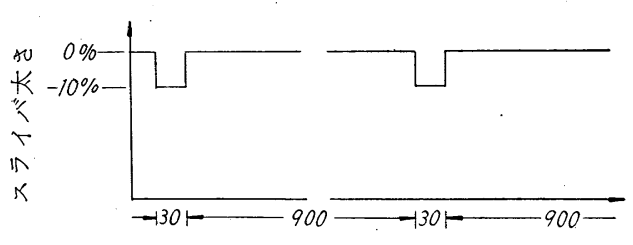

時 間 $(\mathrm{sec})$

（第 14図）SRD絠出量目の推移

このように自動第一練条機での紡出量目が突変するが 静的な特性からは, 自動仕上練条機の制御装置の管理範 囲内であるから問題はない。乙かし動的な特性からは当 然問題になる.

このように突変が与えられたスライバが, 自動仕上練 条機に供給されたときの制御装置の挙動は，その過渡応 答を゙しらべることによって理解される。それを図解した のが第 15 図である.

第 15 図に沶いて供給スライバが $10 \%$ だけ $Z(t)$ 図 のよ5に突変したとする，それに対してフロントロー

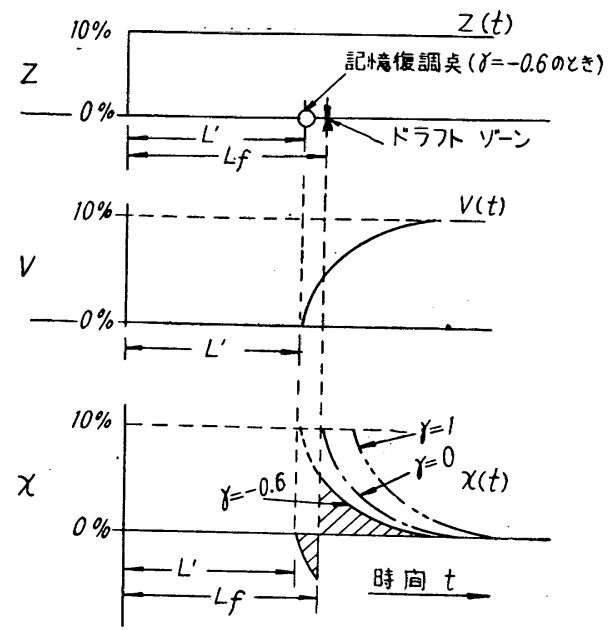

（第 15 図）

スライバ1本オンーオフによるS ADの制御動作

ラの速度は検出がされてから $L^{\prime} \sec$ をへた後に， $V(t)$ 図のように変化をする。したがって $\gamma=-0.6$ に兄らん だ場合には，その紡出量目は $x(t)$ 図の斜線をほどこし た部分のような变動が残る。図には $\gamma=1$ と $\gamma=0$ との 場合を併記した。このような突変を考えた場合にも $\gamma=$ -0.6にえらんで抢くことが，最もむらの発生を少なく することがわかる。すなわちごく短い最高で士 $5 \%$ 程度 のむらが残ることになる．しかしこのむらはごく短い時 間に限られたもので，ドラフト作用自身が一つの容量和 くれをるつるのであるから，これほどシャープにむらが 現われるものではなく，もっと平滑化された形に現われ るものと考えられる．実用的にはほとんど問題になった ことはない。

\section{5. 簡易セルシンによる同期運転}

まえにも述べたように，1\%以上の速度差があると， 正常な運転は望めない，そこでカード群の速度と，それ に連なる自動第一練条機および自動仕上練条機抽よびそ の間をつなぐスライバコンベヤの速度制御が必要にな る.カードの起動および停止は大きい慣性を伴うが，他 は攺とんど慣泩がなく，両者の特泩は全くことなってい る。

このような制御には直流モータを用いるセクショナル ドライブの方法が適用されることが多い．しかしこの方 法は設備費が高価で，しかも直流を特別に用いるので， あまり好ましくない。

設備費もあまり高価でなく，乙か子交流をそのまま用 いる方法の一つとして，簡易セルシンの方法がある。こ 


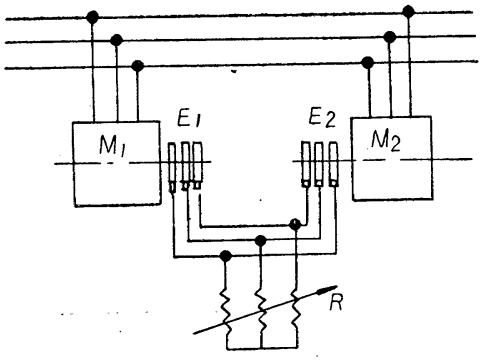

（第 16 図）

共通 2 次抵抗を有する巻線形誘導霞動機の結線

こでもとの方法を用いている.

原理的にそれを説明するため，第16図にその原理を 示す. $M_{1}, M_{2}$ の 2 つの電動機によって伝動されている 2 つの機珹の同調運転を考える. $M_{1}$ b $M_{2}$ も巻線形誘 導電動機で, 巻線に共通 2 次抵抗 $R$ を有している. 起 動に際しては共通 2 次抵抗 $R$ を比較的大にして, 加速 時間を長くして, 順次減少してつねに 20〜30\%のすへ りを有するように $R$ を残す。

起動時の 2 次誘起電圧 $E_{1}, E_{2}$ の差によって生ずる 2 次回路内の電流 $I_{c}$ は $E$ よりもほぼ $90^{\circ}$ おくれの電流 (第 17 図参照) である。これらが同期化電力になる. 加

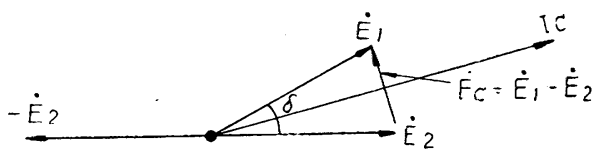

（第 17 図）同期化霞力のベクトル

速があまりはやくなく，同期化電力が減衰振動をすると き，スムースに起動がされる．定常状態では各機は同一 のすべりで回転するわけであるが，回転速度および負荷 の不平等の誙容程度は, 近似的に

$$
|| W_{1}-a p_{1}|-| W_{2}-a p_{2}||<F
$$

ここに

$W_{1}, W_{2}$ : 電動機の定格出力

$p_{1}, p_{2}$ : 各機の機械出力 (実効值)

$a:$ 各機の熱損失を考慮した係数 (ほぼ 1.3 程度)

$F$ : 同期化力（電動機の定数できまる）

したがって，負荷の不平等がなるべくないことが，同 期をよくすることになる，そこでそれをなるべく避け， 同期化を円滑にするために，SRD，SADの伝動用モ ータには，適当なフライホィールをつけて，カードの 回転特性に近づけてある.そのような対策をとって後, 起動および停止時の回転特性を測定したのが第 18 図で

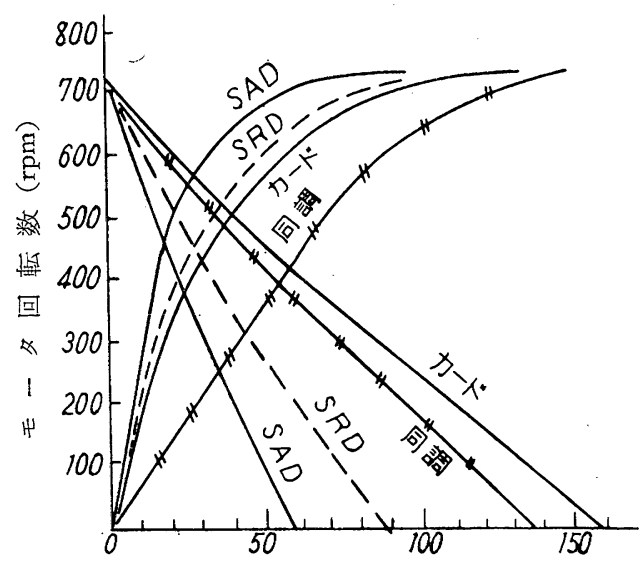

時 間 $(\mathrm{sec})$

（第 18 図）各モータの回転特性

ある.ただし SRD，SAD のモータはカードのモー タの 2 倍の同期速度にしてある（フライホィールの関 係) ので, 図では $1 / 2$ の目盛がいれてある.

無理なく起動，停止を行なうために，図には＋印の 実線で示したような，過渡速度を同調速度としてえらん でいる．定常運転時にも $25 \%$ 程度のすべりを与えて同 期運転を確保するように共通抵抗 $R$ を残すようにして いる.

\section{UHD 精紡機の性能}

従来の一般工程に㧊いても，シンプレックス粗紡機を 用いる場合には，もはや粗糸は重合の機会は与えられず 1 本の仕上練条スライバがドラフトされて 1 本の粗糸と なり,、㹩の1本の粗糸が，さらにドラフトされて 1 本の 精紡系になるわけである。したがってドラフトを粗紡と 精紡との 2 つ程に分けて，こきざみに与える理由は ない. シンプレックス粗紡で 7 倍，精紡で 50 倍のドラ フトを与えるとすれば，1本のスライバに与えられたド ラフトは 350 倍である。したがって精紡台上で，多線口 一ラ和よびェプロンの組合せで，一挙に 350 倍のドラフ トを与えても, ドラフトという面ではなんら不合理はな いわけである.ここでウルトラハイドラフト方式と普 通方式とがちがっている点は，

(a) 粗糸よりの効果が期待できないこと

(b) 粗糸での方向反転効果がないこと の 2 点である.

(a) についてはエプロン効果を充分生かすこと, ド ラフト中にスライバを幅方向に，3つ折りにするような コレクタを用いることなどで充分効果をあげ得る.

(b) については要するに, スライバ中の縤維が前方 
向にも, 後方向にも, まったく平行度に差がないように そろったスライバを用いれば反転の効果は不要になる. B CDユニットのスライバは，SRDの優れた効果によ って, この条件を満足している.

それらのことに反して粗紡工程は，前後列スピンドル による粗系の張力不同の問題やレャーによる巻取径に 対して，ボビン回転数の極微調整が因難な問題など，と かく不評の多い工程である。したがって総合的にみて， 多線ローラとエプロンの組合せと，コレクタを有効に用 いることによって，スライバから一挙に精紡系に仕上げ た㴗うが合理的である。むしろ問題はいかにして，太い スライバを要領よくパッケージにまとめて，スピンドル ゲージの限られた精紡台上に供給するかにある．このこ とは将来とも検討さるべき課題である.

UHD精紡機のドラフトパートを第19 図に示す。装 置Aは高番手用のもので, 主ドラフトはすべてェプロン パートで与方れるようにしてある，装置Bは低番手用 のもので, 主ドラフトはェプロンパートで1回, ロー
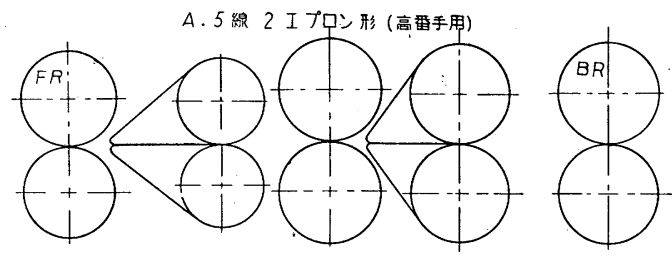

8.4線1工プン形 (低番手用)

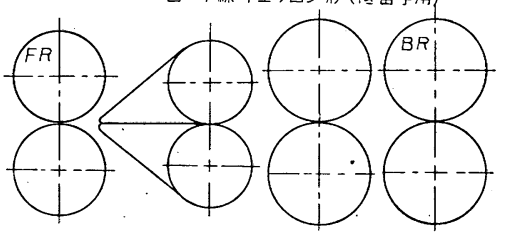

（第 19 図）UHD精䋡機ドラフトパート

ラパートで1回与兄られる。他はブレークドラフトあ るいはドラフト準備のゾーンに使用されるが，このこと は装置Aについても同じである.

下表にこれらの装置を用いて得られた系のだいたいの 水準をあげる，いずれも $40 \mathrm{~s}$ である，装置Bによって

\begin{tabular}{|c|c|c|c|c|}
\hline 装置 & 外観系条 & $U \%$ & 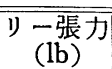 & 備＼cjkstart考 \\
\hline B & 2.7 号 & $16.6 \sim 17.2$ & $54 \sim 57$ & $\begin{array}{l}\text { スペクトル } \\
2 \mathrm{yd} \text { 周期残る }\end{array}$ \\
\hline A & ほぼ 2 号 & $15.5 \sim 16.0$ & $58 \sim 60$ & $\begin{array}{l}\text { スペクトル } \\
\text { ほとんと゚なし }\end{array}$ \\
\hline
\end{tabular}

も $40 \mathrm{~s}$ は紡出可能であるが成績は香しくない，ただし 系ざれは案外少なくてすみ，管理は装置Aよりも容易で あり，低番手または化績糸用としては適している。
いままではドラフト装置を検討する場合に, ウースタ \%や，糸の板巻試験による糸しの判定とか，せいぜいス ペクトログラフを参考にして，直感的な方方法で検討を行 なった。しかしそのいずれもをパスした絡が，製織され た場合に問題をおこすことは，しばしば経験するところ である，そこでここでは，正確に糸むらの自己相関関数 を計算することによって，新しい情報を得て，判定する ことを試みた。るちろんスペクトログラフもその意図を あつものであり, 試験器としてはまさに画期的で優れた ものであるが，このような目的には装置が簡単にすぎて 精度に乏しい。

ここで用いた装置は, 試作したアロナグ形相関器であ る.この相関器に入れる信号は, 電圧に变換されて和れ ばなんでもよいわけであるが，いるの場合はウースタ 信号をそのます録音器にかける。録音器は信号をパルス 幅変調して, デイジタル化し, 磁気テープにいれる. 録 音された磁気テープは, 演算器にかける。. 演算器ではへ

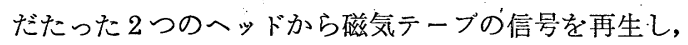
復調して掛算器で両値をかけあま女積分器に入れて, 解 を得るようになっている，その詳しい構造および応用に ついては別報にゆずり，ここでは結果だけをあげる。

第 20 図にその演算結果を示す。曲線 a は装置Aで, 曲線 bは装置 Bで紡出された $40 \mathrm{~s}$ 単糸の計算結果を示 し, 曲線 c は一応よいとみなされる一般糸の計算結果を 示す.

以上の結果を総合すると，装置 $\mathrm{B} て ゙ は ~ 40 \mathrm{~s}$ 紡出は無 理であって，るっと低番手の紡出に用いるべきであるこ

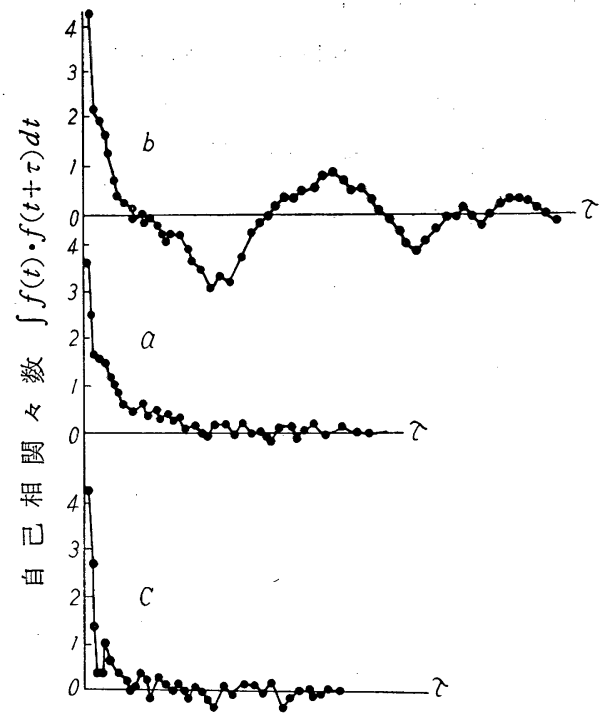

（第 20 図）糸むらの自己相関々数 
とは明らかである。

装置Aでは，ドラフト 360 倍としても実用上支障がな く, 一般在来工程による糸に比しても優るとも劣らない 糸が得られていることがわかる.

\section{7. 結 び}

C A S システムの特性について主として述べたが，C A S の研究はいまな拀つづけられており, この一文では 到底つくせるものではなく, ほんの“さわり”を述べた にすぎないところも多くあった，専門的な研究について は，別の機会にゆずることにしたいが，またさらに専門 別にほり下げた研究では，それぞれその担当者から発表 される機会もあろ5.

ここでは主として特泩の基礎的な分野を述べたわけで あるが，その結果を要約すれば

（1）リザーブボックス給綿では，ピアノモーショ ンに類する定量供給の必要はない.

（2）ブランチ コンベヤの給綿量は，（7）式にした がえば安定であるが，綿層レベルを考えてあまり小さく とることは好ましくない。

（3）自動仕上練条機のゲイン調整注（14）式によっ て正確に行ない, 記憶時間の設定は $\gamma=-0.6$ にする.

（4）自動第一練条機の考案は, 工程結合に重要な寄 与をした.また自動仕上練条機で $\gamma=-0.6$ の記憶時間 の設定が，この工程では必須の要件になる.

（5）簡易セルシンによる同期運転は, 負荷の不圴衡 を避けるために，カードに比して慣性の小さいスライバ コンベヤ，SRD，SAD用のモータには，適当なフラ イホィールをつける必要がある。

（6）超ハイドラフト精紡機は, 紡出条件を適正にす れば，実用的に成功である．ただしスライバのドラフト ゾーンへの供給方法は開発する必要がある.

\section{参考文献}

1）村上, 加瀬；第21回年次大会前刷 村上; 制御工学, 2, 3 (1957-3) 村上, 正満, 加瀬; 制御工学, 5, 4. (1960-4)

2 ）村上, 正満, 加瀬; 本誌, 12, 4（1959-4)

注

1）混打綿機は原則的に在来機と変りがなく, 改造の 場合には，ほとんどそのまま転用が可能である。

2）CASでは連続運転が必要で，並掃除や摩針をし ないですむメタリック化をする必要がある。T C A (Toyobo Card Analizer) を装置するととが 望末しい。

3 ）改造の場合は在来カードを転用してもよいが，新 設の場合は 2 群のマルチカード〔6を用いると便利 である。

4) 工場構成の都合により, 従来の粗紡, 精䋡の 2 3 工程方式を用いる場合にも， B C Dニニットあ がりスライバを粗綘に仕掛けるととは有効であ る. 従来工程よりる品質は向上し, 均質な生産が 得られ，能率は増進する。

5 ) さらにCASシステムの構成をブロックダイヤグ ラムで示したものが第 2 図である。またCAS工 場の実際を写真 1 （a),（b ）に示し, UHD精 絃機とオートドッファ（TAD）を写真 2 と示す.

6) プランチコンベヤの綿は同時に数個のリザープ ボックスには投入できない，ただ1個のリザープ ボックスだけに括ちるようになっている。

7) あをらかに $Z_{0} / x_{0}=d_{0}$ である。

8 ）強力扣よび強力変動などはもちろん参考にしなけ ればならない。 